\title{
STRATEGI MARKETING PUBLIC RELATIONS UNTUK MEMBANGUN CITRA INNISFREE MELALUI PENGGUNAAN VIRTUAL REALITY
}

\author{
Fathia Ramadani ${ }^{1}$, Kiki Rizqi Sofia ${ }^{2}$ \\ Fakultas Ilmu Komunikasi, Jurusan Public Relations, STIKOM The London School of Public Relations \\ J1. K.H. Mas Mansyur Kav.35, Jakarta Pusat, DKI Jakarta, 10220, Indonesia \\ No. Telp./HP: (021) 57942471 \\ E-mail: ${ }^{1}$ ramadanifathia@gmail.com, ${ }^{2}$ kikirizqisofia@gmail.com
}

Naskah diterima pada tanggal 18 April 2019, direvisi tanggal 19 Agustus 2019, disetujui tanggal 29 Oktober 2019

\section{MARKETING PUBLIC RELATIONS STRATEGY TO BUILD IMAGE OF INNISFREE THROUGH THE USE OF VIRTUAL REALITY}

\begin{abstract}
This research is about the marketing public relations strategy to build a brand image of Innisfree through the use of Virtual Reality (VR). It is essential to enhance the brand in the middle of intense competition in the beauty industry in Indonesia to gain public interest. This research aims to analyze the marketing public relations strategy to build a brand image of Innisfree through the use of VR. This research uses a qualitative method with a descriptive attribute. The collection of primary data is through in-depth interviews with the internal and external informant, dan secondary literature study. The examination of data credibility is using source triangulation. According to the result from a pull strategy i.e., performed online publications, holding media events, online competition, and carry out the survey directly as well as an online survey.
\end{abstract}

Keywords: CMC theory, marketing public relations, image, publication, virtual reality.

\begin{abstract}
Abstrak. Penelitian ini membahas mengenai strategi marketing public relations untuk membangun citra Innisfree melalui penggunaan Virtual Reality (VR). Meningkatkan citra brand di tengah gencarnya persaingan dalam industri kecantikan Indonesia tentunya penting dilakukan untuk memenangkan perhatian publik. Tujuan dari penelitian ini adalah untuk menganalisis strategi marketing public relations melalui penggunaan virtual reality untuk membangun citra Innisfree. Penelitian ini menggunakan metode kualitatif dengan sifat deskriptif. Pengumpulan data primer dilakukan dengan wawancara mendalam (indepth interview) dengan informan internal, informan eksternal, beserta studi kepustakaan sekunder. Pemeriksaan keterpercayaan data dengan triangulasi sumber. Berdasarkan hasil temuan dari strategi pull yaitu melakukan pemberitaan online, mengadakan media event, kompetisi online, dan melakukan survei baik secara langsung maupun online.
\end{abstract}

Kata kunci: teori CMC, marketing public relations, citra, publikasi, virtual reality.

\section{PENDAHULUAN}

Di zaman serba modern ini telah memberikan berbagai kemudahan dan kepraktisan untuk menunjang penampilan, salah satunya adalah pemakaian produk perawatan atau kosmetik. Kosmetik dikenal manusia sejak berabad-abad yang lalu. Pada abad ke-19, pemakaian kosmetik mulai DOI: $10.20422 / j p k . v 22 i 2.635$ mendapat perhatian, selain untuk kecantikan juga untuk kesehatan (Tranggono \& Latifah, 2007).

Media dengan unsur pembeda yang tepat merupakan salah satu strategi yang dapat meningkatkan daya jual serta daya saing dengan merek kosmetik lainnya. Untuk itu, diperlukan peranan penting dari marketing public relations untuk dapat 
mengembangkan strategi dengan cara yang maksimal.

Kosmetik Korea Selatan menjadi salah satu yang cukup agresif memasuki pasaran Indonesia. Sejumlah merek kosmetik asal Korea terlihat gencar menggelar kampanye komunikasinya. Berdasarkan data yang dirilis Mix.co.id pada laman resminya, ada enam merek Korea yang dikenal dan diminati wanita maupun pria Indonesia berusia 16-35 tahun. Terdapat tiga merek kosmetik Korea yang merajai pasar kosmetik di Indonesia. Berdasar hasil survei tersebut, 71,17\% pernah membeli dan menggunakan merek Etude House. Disusul oleh The Face Shop sebesar $39,05 \%$, dan Nature Republic 14,96\%. Tiga merek lainnya adalah Missha 12,77\%, Innisfree 9,12\%, dan Aritaum 12,9\% (Wulandari, 2016)
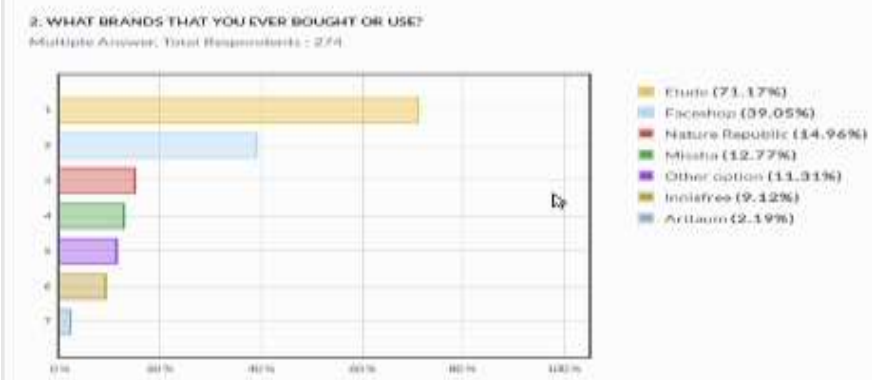

Sumber: Wulandari (2016)

Gambar 1. Merek kosmetik Korea yang diminati masyarakat Indonesia

Kemajuan industri kecantikan di Indonesia saat ini mengalami peningkatan yang cukup signifikan. Produk kosmetik baik lokal maupun impor semakin membanjiri pasar Indonesia. Berdasarkan data dari Kementerian Perindustrian (Kemenperin, 2016), lebih dari 760 perusahaan kosmetik tersebar di seluruh Indonesia dan pertumbuhan pasar industri ini rata-rata mencapai $9,67 \%$ per tahun dalam enam tahun terakhir (2009-2015). Diperkirakan besar pasar (market size) kosmetik mencapai 46,4 triliun rupiah pada tahun 2017. Dengan jumlah tersebut, Indonesia menjadi pasar potensial bagi para pengusaha industri kecantikan baik dari luar maupun dalam negeri (Kemenperin, 2016).

Setiap merek membutuhkan marketing public relations untuk melakukan promosinya sehingga dapat membangun citra yang diinginkan. Dinamika pencitraan pada produk ataupun merek jauh lebih dinamis daripada citra korporasi, karena daur hidup produk yang singkat dengan sendirinya menciptakan aktivitas yang lebih kuat. Merek maupun produk berhubungan langsung dengan konsumen sehingga diwajibkan untuk beradaptasi lebih sering dengan mengikuti selera konsumen. Ketika harus memahami citra merek, seorang praktisi public relations (PR) harus memahami konsep dasar pemasaran (Wasesa \& Macnamara, 2010).

Innisfree sebagai merek kosmetik Korea pertama berkonsep natural yang mengusung produk-produk alami, serta senantiasa berusaha untuk mempersembahkan energi alam yang bersih dan murni guna mewujudkan kecantikan yang sehat. Innisfree merupakan sebuah brand yang mempersembahkan manfaat alam pulau Jeju nan kaya yang menyediakan kecantikan alami yang menyeimbangkan konsep hidup berdampingan antara manusia dengan alam dengan mempertahankan keasriannya (Innisfree, 2017).

Innisfree membuat sebuah inovasi baru dengan memperkenalkan produk Innisfree melalui sebuah teknologi yang sedang berkembang saat ini yang dikenal dengan virtual reality. Inovasi tersebut dilakukan Innisfree dengan tujuan agar tetap mempertahankan eksistensi di dunia kosmetik serta mencapai citra yang diinginkan oleh Innisfree sebagai merek 
dengan konsep natural yang terdepan dalam bidang teknologi.

VR pada dasarnya adalah sebuah representasi tiga dimensi dari lingkungan yang tidak nyata, terutama karena simulasi yang dihasilkan komputer, komputasi, dan visualisasi adalah kunci dari teknologi ini (Saggio \& Ferrari, 2012).

Virtual reality yang digunakan oleh Innisfree bertujuan agar dapat mencapai citra yang ingin diciptakan oleh Innisfree, yang mana Innisfree tidak hanya ingin dikenal sebagai merek dengan konsep natural, tetapi Innisfree juga ingin dikenal sebagai merek kosmetik yang terdepan dalam bidang teknologi.

Atas dasar latar belakang masalah yang telah dijabarkan, peneliti melakukan penelitian mengenai strategi marketing public relations untuk membangun citra Innisfree melalui penggunaan virtual reality. Tujuan dari penelitian ini adalah untuk memperoleh gambaran dalam menganalisis strategi marketing public relations melalui penggunaan virtual reality untuk membangun citra produknya kepada khalayak luas dan penelitian ini diharapkan dapat menambah kekayaan keilmuan khususnya dalam bidang Ilmu Komunikasi dan teori-teori yang berkaitan dengan marketing public relations serta untuk memperlihatkan kajian tentang Penggunaan virtual reality guna membangun suatu citra.

Tabel 1

Hasil Penelitian sebelumnya

\begin{tabular}{|c|c|c|c|}
\hline No & $\begin{array}{c}\text { Ukuran } \\
\text { Komparasi }\end{array}$ & Penelitian I & $\begin{array}{c}\text { Penelitian } \\
\text { Peneliti }\end{array}$ \\
\hline \multirow[t]{4}{*}{1} & Judul & Peningkatan & Marketing \\
\hline & & Awareness PT.Gojek Indonesia & Relations Untuk MembanguCitra \\
\hline & & Melalui Aktivitas Marketing Public & Innisfree Melalui Penggunan \\
\hline & & Relations (Wahid \& Puspita, 2017) & Virtual Reality (VR) \\
\hline 2 & Peneliti & Umaimah dan Eka A.P & Fathia Ramadani \\
\hline 3 & Tahun & 2017 & 2017 \\
\hline \multirow[t]{2}{*}{4} & Konsep & Marketing Public Relations (7 Alat & Marketing Public Relations (3 \\
\hline & & $\begin{array}{l}\text { Utama MPR: Publication, Event, } \\
\text { News, Community Involvement, } \\
\text { Image, Lobbying, CSR) }\end{array}$ & Ways Strategy: Pull Strategy) \\
\hline 5 & Metode & Eksploratif Kualitatif & Deskriptif Kualitatif \\
\hline 6 & Teknik & Observasi, Wawancara & Observasi, Wawancara \\
\hline 7 & Temuan Penelitian & $\begin{array}{l}\text { PT.Gojek Indonesia berhasil } \\
\text { mendapatkan citra positif dari } \\
\text { masyarakat dilihat dari loyalitas } \\
\text { yang diberikan oleh pelanggan dan } \\
\text { Gojek mampu memperkenalkan } \\
\text { perusahaan dengan memberikan } \\
\text { pelayanan yang berbeda dari } \\
\text { competitor }\end{array}$ & \\
\hline
\end{tabular}

Sumber: Hasil Penelitian

\section{LANDASAN KONSEP}

\section{Marketing Public Relations}

Istilah marketing public relations pertama kali dicetuskan oleh Thomas L. Harris (Harris \& Whalen, 2006), dikatakan bahwa marketing public relations adalah sebuah proses perencanaan dan pengevaluasian program yang merangsang penjualan dan pelanggan. Hal tersebut dilakukan melalui pengomunikasian informasi yang kredibel dan kesan-kesan yang dapat menghubungkan perusahaan, produk dengan kebutuhan serta perhatian pelanggan.

Konsep marketing public relations secara garis besar menurut Thomas L. Harris (Harris \& Whalen, 2006) terdapat tiga taktik (three ways strategy) untuk melaksanakan program dalam mencapai tujuan, yaitu: 
Public relations merupakan potensi untuk menyandang suatu taktik pull strategy (menarik). Power (kekuatan) sebagai penyandang, push strategy (untuk mendorong) dalam hal pemasaran. Pass strategy sebagai upaya memengaruhi atau menciptakan opini publik yang menguntungkan.

Program marketing public relations tersebut di satu sisi, merupakan upaya untuk merangsang ( $p u s h)$ pembelian dan sekaligus dapat memberikan nilai-nilai (added value) atau kepuasan bagi pelanggan yang telah menggunakan produknya. Di sisi lain melalui kiat public relations dalam menyelenggarakan komunikasi timbal balik dua arah yang didasari oleh informasi dan pesan-pesan yang dapat dipercaya, diharapkan dapat menciptakan kesan-kesan positif terhadap lembaga yang diwakilinya. Hal ini merupakan "sinergi" peranan Corporate Public Relations (CPR) dari taktik pull strategy (strategi untuk menarik), yang kemudian diikuti dengan taktik selanjutnya pass strategy (strategi untuk membujuk) untuk mendukung demi mencapai tujuan dari marketing public relations.

\section{Citra}

Menurut Frank Jefkins (Jefkins, 2002) dalam bukunya yang berjudul Hubungan Masyarakat, ada beberapa jenis citra (image) yang dikenal di dunia Public Relations, dan dapat dibedakan satu dengan yang lainnya, di antaranya.

- Citra Cermin (Mirror Image), dimana setelah diadakan studi tentang tanggapan, kesan dan citra di masyarakat ternyata terjadi perbedaan antara yang diharapkan dengan kenyataan citra di lapangan, bisa terjadi justru mencerminkan "citra" negatif yang muncul.

- Citra Kini (Current Image). Citra merupakan kesan yang baik diperoleh dari orang lain tentang perusahaan/organisasi atau hal yang berkaitan dengan produknya.

- Citra Keinginan (Wish Image). Citra keinginan ini adalah seperti apa yang ingin dan dicapai oleh pihak manajemen terhadap lembaga/perusahaan, atau produk yang ditampilkan tersebut lebih dikenal good awareness, menyenangkan dan diterima dengan kesan yang selalu positif (give and take) oleh publiknya atau masyarakat umum.

- Citra Perusahaan (Corporate Image). Jenis citra ini adalah yang berkaitan dengan sosok perusahaan sebagai tujuan utamanya, bagaimana menciptakan citra perusahaan yang positif, lebih dikenal serta diterima oleh publiknya, mungkin tentang sejarahnya, kualitas pelayanan prima, keberhasilan dalam bidang marketing, dan hingga berkaitan dengan tanggung jawab sosial, dan sebagainya.

- Citra Majemuk (Multiple Image). Citra ini merupakan citra pelengkap dari citra perusahaan di atas, misalnya bagaimana pihak humas/PR akan menampilkan pengenalan (awareness) terhadap identitas perusahaan, atribut logo, brand name, seragam para front liner, sosok gedung, dekorasi lobby kantor, dan penampilan para profesionalnya.

- Citra Penampilan (Performance Image). Citra penampilan ini lebih ditujukan kepada subjeknya, bagaimana kinerja dan penampilan diri para profesional perusahaan bersangkutan.

- Citra tidak hanya terdiri dari sebuah realitas tunggal yang dipegang oleh individu, tetapi juga mereka yang memegang serangkaian gambaran yang saling terhubung yang terdiri dari banyak unsur atau objek yang menyatu dan yang diinterpretasikan melalui bahasa (Oliver, 2007).

\section{Computer Mediated Communication}

Menurut Jerald (2016), komunikasi merupakan interaksi yang terjadi antara dua orang atau lebih. Komunikasi juga dapat terjadi antara manusia dan teknologi, salah satunya adalah virtual reality. Desain $V R$ berkaitan dengan komunikasi tentang cara kerja dunia virtual, bagaimana dunia dan objeknya dikontrol, dan hubungan antara pengguna dan konten idealnya adalah ketika pengguna berfokus pada pengalaman daripada teknologi. Komunikasi dalam VR 
dibagi menjadi komunikasi langsung dan komunikasi tidak langsung.

\section{Komunikasi Langsung (Direct Communication)}

Dalam $V R$, pengembang memasukkan perantara buatan (antara pengguna dan rangsangan sensorik yang dikontrol secara hati-hati (misalnya, bentuk, gerakan, suara). Tujuannya adalah untuk menciptakan komunikasi langsung, pengembang $V R$ harus fokus untuk membuat perantara yang transparan sehingga pengguna merasa seolah-olah memiliki akses langsung ke entitas tersebut. Jika hal tersebut bisa tercapai, maka pengguna dapat melihat, menafsirkan, dan berinteraksi seolah-olah mereka melakukan komunikasi secara langsung dengan dunia maya dan entitasnya. Komunikasi langsung terbagi menjadi komunikasi struktural dan komunikasi visceral.

\section{Komunikasi Struktural}

Untuk dapat menciptakan pengalaman orang lain melalui $V R, V R$ menyajikan rangsangan struktural berupa resolusi layar, suara melalui headphone, atau getaran dari controller, sehingga pengguna dapat merasakan dan berinteraksi secara langsung.

\section{Komunikasi Visceral}

Komunikasi visceral adalah bahasa yang terbentuk secara otomatis yang tergambar melalui emosi. Contoh dari komunikasi visceral dari sudut pandang $V R$ adalah perasaan yang tercipta ketika bersama seseorang melalui kontak mata (melalui avatar di VR).

\section{Komunikasi Tidak Langsung (Indirect Communication)}

Komunikasi tidak langsung yang terjadi di $V R$ adalah tentang bagaimana dunia $V R$ bekerja. Misalnya, interpretasi dari apa yang terjadi di dunia $V R$ dan interaksi tidak langsung seperti memindahkan slider untuk mengubah objek atau tampilan maupun isyarat secara tidak langsung dengan menunjukkan isyarat dan gestur ke arah komputer dari hasil interaksi yang ditampilkan dalam $V R$.

\section{METODE PENELITIAN}

Penelitian ini dilakukan dengan menggunakan metode deskriptif kualitatif, yang menitikberatkan pada observasi dan suasana alamiah (natural setting), peneliti terjun langsung ke lapangan, bertindak sebagai pengamat (Ardianto, 2010). Penelitian ini menggunakan analisis kualitatif dengan studi deskriptif. Penelitian ini dimanfaatkan untuk menjelaskan mengenai strategi marketing public relations yang dilakukan oleh Innisfree untuk membangun citra produk Innisfree di pasar kosmetik.

Dalam penelitian ini, sumber data menggunakan sampel purposif yang memfokuskan pada informan-informan yang terpilih yang kaya dengan kasus untuk studi yang bersifat mendalam (Sukmadinata, 2007). Sampel purposif digunakan untuk memudahkan peneliti untuk membuat kriteria sampel agar sesuai dengan penelitian yang akan dilakukan. Guna mendukung penelitian ini, narasumber yang digunakan adalah narasumber yang berhubungan langsung dengan pelaksanaan kegiatan $M P R$ Innisfree, yaitu:

\section{Marketing Communication Manager}

Peneliti memilih perwakilan dari Marketing Communication Manager Innisfree untuk dapat mengetahui kegiatan Marketing Public Relations apa saja yang telah dilakukan oleh Innisfree. Tentunya data ini sangat penting untuk menunjang penelitian ini.

\section{Customer dan Non-Customer Innisfree}

Peneliti juga memerlukan pendapat dari konsumen Innisfree sebanyak empat orang untuk melihat apakah benar kegiatan Marketing Public Relations yang dilakukan oleh Innisfree memberikan dampak yang signifikan untuk membangun citra produk Innisfree di pasar kosmetik.

Penelitian menggunakan teknik pengumpulan data menggunakan wawancara mendalam (indepth interview), studi literatur melalui buku, internet, jurnal dan website resmi. Paradigma yang digunakan dalam penelitian ini adalah paradigma konstruktivis dan menggunakan sebanyak 
lima orang yang diwawancarai sebagai narasumber.

Penelitian ini menggunakan triangulasi sumber sebagai uji validitas data di dalam penelitian ini. Peneliti akan membandingkan data hasil observasi dengan data yang didapatkan dari hasil wawancara dengan beberapa sumber yang telah dipilih.

Tabel 2

Daftar Informan

\begin{tabular}{|c|c|c|c|}
\hline No & Nama & Jabatan & Keterangan \\
\hline 1 & Jihan Rizkia & $\begin{array}{l}\text { Marketing } \\
\text { Communication } \\
\text { Manager }\end{array}$ & Informan Kunci \\
\hline 2 & Natasya Putri & Mahasiswi & $\begin{array}{l}\text { Pengguna Baru } \\
\text { VR Innisfree }\end{array}$ \\
\hline 3 & Astri Rizkia & $\begin{array}{l}\text { Karyawan } \\
\text { Swasta }\end{array}$ & $\begin{array}{l}\text { Pengguna Lama } \\
\text { VR Innisfree }\end{array}$ \\
\hline 4 & Riane Anggrainy & Mahasiswi & $\begin{array}{l}\text { Non Pengguna } \\
\text { VR Innisfree }\end{array}$ \\
\hline 5 & Yolanda Shafira & $\begin{array}{l}\text { Karyawan } \\
\text { Swasta }\end{array}$ & $\begin{array}{l}\text { Non Customer } \\
\text { Innisfree }\end{array}$ \\
\hline
\end{tabular}

\section{HASIL PENELITIAN DAN PEMBAHASAN}

AmorePacific Corporation (PT. Laneige Indonesia Pacific) adalah perusahaan kosmetik dan kecantikan global yang berasal dari Korea Selatan yang didirikan sejak tahun 1945. Perusahaan ini mengoperasikan 34 merek kesehatan, kecantikan, dan perawatan pribadi termasuk Etude House, Innisfree, Laneige, Hera, Mamonde, Sulhwasoo dan masih banyak lagi. Kesuksesannya saat ini menjadikan AmorePacific Corporation sebagai perusahaan kosmetik terbesar ke-14 di dunia.

Innisfree merupakan merek kosmetik yang berkonsep natural pertama dari Korea Selatan yang berdiri pada tahun 2000 .

Innisfree memperkenalkan sebuah merek yang mempersembahkan seluruh manfaat alam Pulau Jeju yang kaya akan penghasil kecantikan nan alami dimana alam murni dan kecantikan nan sehat berpadu dalam kesatuan harmoni.

Innisfree menciptakan ruang dimana alam dan kulit bisa beristirahat dalam energi hijau Jeju yang murni, sehingga hal ini membuat Innisfree ingin berbagi dengan seluruh penggunanya.

\section{Strategi Pull Marketing Public Relations}

Strategi pull marketing public relations dapat dilakukan dengan berbagai macam komunikasi. Seperti yang dilakukan oleh Innisfree dalam menarik minat publik terhadap produknya yaitu dengan melakukan pemberitaan secara online. Semakin banyak pemberitaan yang disebarkan, maka semakin banyak pula masyarakat yang mengetahui dan tertarik.

Tidak hanya melalui pemberitaan secara online, strategi yang dilakukan oleh Innisfree dalam menarik minat publik untuk menonton tayangan $V R$ Innisfree adalah melalui leaflet yang tersedia di setiap gerai seluruh Innisfree. Innisfree juga selalu berkoordinasi dengan beauty advisor mereka untuk menarik minat publik dalam menonton tayangan $V R$ Innisfree.

Hal tersebut sesuai dengan penjelasan dari informan internal yaitu $M P R$ Manager Innisfree sebagai berikut:

"Yang pasti secara online, karena buat kita online itu komunikasi yang paling mudah dan paling murah untuk me-reach customer atau target audience kita. Jadi setiap video dari $V R$ ini selalu kita iklankan either itu lewat Facebook Ads, Instagram Ads atau iklan kayak GDN, dan Youtube. Dan itu sih menurut kita cukup efektif dan efisien. Terus yang kedua kita punya leaflet 
di toko. Leaflet tentang Virtual Reality yang kita sebarkan juga ke customer-customer khususnya customer baru. Kemudian kita juga selalu brief Beauty Advisor kita di toko kalau misalnya memang ternyata VR-nya ini lagi tersedia, mereka bisa coba."

Penjelasan tersebut memiliki keterkaitan dengan konsep dari (Kotler, Keller, Ang, Leong, \& Tan, 2009) mengenai alat-alat utama dari Marketing Public Relations salah satunya adalah publikasi. Perusahaan bergantung erat pada bahan yang dipublikasikan untuk menggapai dan memengaruhi target pasarnya. Termasuk di dalamnya membuat laporan tahunan, brosur, artikel, koran perusahaan, majalah, dan materi audio visual. Melalui publikasi tersebut sasaran yang dituju menjadi lebih luas dan dapat menciptakan suatu opini publik dan mampu memersuasi publik secara luas.

Dengan memilih kaum millenial yang berusia sekitar 18-35 tahun sebagai bagian dari target pasarnya, Innisfree juga menawarkan pilihan kisaran harga yang beragam sehingga hal tersebut dapat dengan mudah menarik minat di berbagai kalangan. Melalui target pasar tersebut, Innisfree turut membuat strategi Marketing Public Relations (MPR) khusus yang berkaitan dengan target pasar dari Innisfree itu sendiri diantaranya strategi penggunaan $V R$ yang tengah berkembang luas saat ini khususnya di kalangan milenial.

\section{Fitur dan Pesan dalam VR Innisfree}

Dalam menjalankan strategi MPR melalui penggunaan $V R$, Innisfree memiliki tiga buah video yang terdapat dalam tayangan $V R$ Innisfree. Dari ketiga video $V R$ tersebut memiliki tiga tema, di antaranya Flying Bike, Someday in Jeju, dan Jeju Wonderland.

Pesan utama yang ingin disampaikan Innisfree melalui penayangan $V R$ yaitu agar target pasar dapat mengetahui dan merasakan berbagai pengalaman yang berbeda terhadap Pulau Jeju di setiap konten yang ditunjukkan serta makna pesan dari video tersebut dapat lebih tersampaikan dengan lebih baik.
"Tiap video $V R$ Innisfree memiliki message masing-masing. Video $V R$ Flying Bike memiliki pesan agar semua orang bisa bersepeda sambil mengelilingi Jeju Island sebagai petualang. Untuk video Someday in Jeju, menggambarkan bahwa Jeju Island adalah tempat yang indah dan romantis, serta orang yang menggunakan VR dapat ikut menarasikan videonya dan bisa interaksi langsung dengan brand ambassador Innisfree yaitu Lee Min Ho. Video Jeju Wonderland sendiri lebih membahas mengenai ingredients produkproduk Innisfree. Jadi, setiap video memiliki message-nya masing-masing." (Jihan, wawancara data primer, 26 Februari 2018).

Innisfree menggunakan pesan melalui $V R$ tersebut karena Innisfree tidak hanya ingin memperkenalkan mereknya sebagai beauty brand dari Korea saja, tetapi juga ingin menonjolkan Pulau Jeju sebagai ikon dari Innisfree itu sendiri. Melalui pesan tersebut, Innisfree secara tidak langsung membuat publik dapat merasakan keindahan dan manfaat dari produk Innisfree menjadi lebih nyata melalui teknologi $V R$ ini.

Penerapan yang digunakan Innisfree sesuai dengan komunikasi struktural dan visceral menurut (Jerald, 2016). Dalam komunikasi struktural, untuk dapat menciptakan pengalaman melalui $V R, \quad V R$ menyajikan rangsangan struktural berupa resolusi layar, suara melalui headphone, atau getaran dari controller, sehingga pengguna dapat merasakan dan berinteraksi secara langsung. Sedangkan dalam komunikasi visceral, efek dari penggunaan $V R$ adalah pemakai dapat merasakan emosi secara langsung melalui kontak mata (melalui avatar yang terdapat dalam $V R$ ).

Adanya penggunaan strategi $M P R$ melalui penggunaan $V R$ telah mendapatkan berbagai tanggapan dari publik. Tanggapan yang diberikan publik kepada Innisfree sejauh yang dirasakan ini adalah tanggapan positif. Tanggapan tersebut diperoleh dari salah satu video $V R$ Innisfree Someday in Jeju telah lebih dulu viral sebelum Innisfree resmi masuk ke pasar Indonesia. Tanggapan positif yang diberikan publik terhadap Innisfree tentu bisa menaikkan citra dari brand Innisfree itu sendiri. 


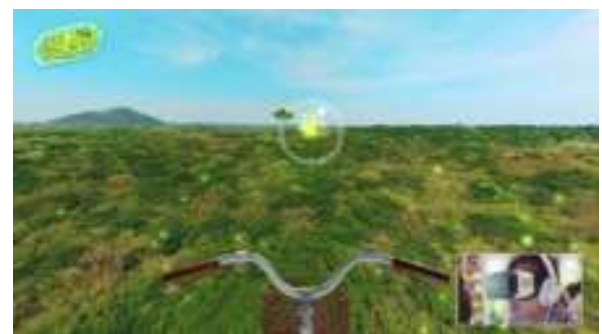

Gambar 2. Innisfree VR Flying Bike, (Innisfree, 2017)

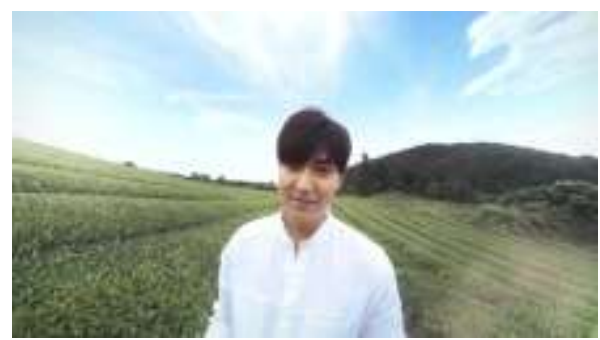

Gambar 3. Innisfree VR Someday in Jeju (Innisfree, 2017)

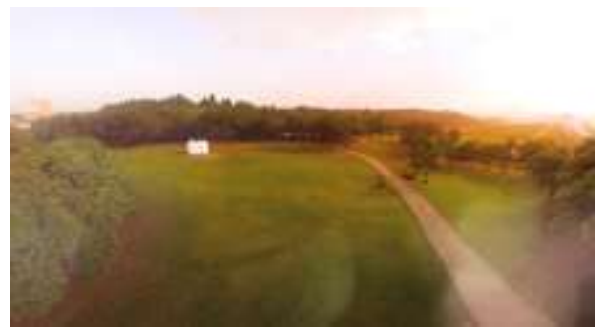

Gambar 4. Innisfree VR Jeju Wonderland (Innisfree, 2017)

Dengan tanggapan positif yang diberikan oleh publik terhadap Innisfree tentu dapat mencerminkan kesuksesan yang didapatkan oleh Innisfree saat ini. Melalui tanggapan tersebut dapat memberikan dampak positif bagi kelangsungan Innisfree ke depannya dan Innisfree mampu mewujudkan citra yang diinginkannya (wish image) sebagai merek berkonsep natural yang terdepan dalam bidang teknologi.

Penjelasan tersebut sesuai dengan konsep menurut (Kotler et al., 2009) tentang peranan Marketing Public Relations dalam upaya mencapai tujuan utama organisasi atau perusahaan dalam berkompetisi salah satunya yaitu membina dan mempertahankan citra perusahaan atau produk barang dan jasa, baik dari segi kuantitas maupun kualitas pelayanan yang diberikan kepada konsumennya.
Setelah merencanakan dan melaksanakan strategi $M P R$, tentunya terdapat saran dari publik terhadap hasil kinerja yang dilakukan oleh suatu perusahaan. Tidak terkecuali bagi Innisfree, setelah melaksanakan strategi $M P R$ yang dibuatnya, tentu Innisfree mendapatkan beragam saran dari hasil kinerjanya melalui masyarakat luas.

Salah satu saran yang didapat oleh Innisfree adalah menyelesaikan kendala bagi pengguna kacamata yang mengaku kesulitan saat mengenakan kacamata $V R$. Sejauh ini, Innisfree telah berupaya memberikan solusi dengan mengumpulkan saran publik dan langsung dikirim ke Korea untuk segera mungkin ditangani. 


\section{Hambatan Pelaksanaan Strategi MPR Innisfree}

Hambatan yang terjadi pada pelaksanaan strategi $M P R$ terhadap penggunaan $V R$ Innisfree memiliki dua hambatan pokok utama yaitu pada hambatan dan fasilitas.

"Karena antusiasme yang cukup tinggi yang menyebabkan $V R$ kita yang belum setahun itu beberapa kali rusak. Jadi sebenarnya lebih ke teknis, kemudian masalah kacamata akan kita develop supaya kedepannya kita bisa mengakomodir orangorang yang punya masalah dengan mata juga. Dan satu lagi mengurus $V R$ agak repot karena setiap hari ada guidance yang harus di ikuti supaya secara teknikal tetap berjalan seperti yang seharusnya. Sebenarnya dari sisi maintaining cost-nya cukup tinggi." (Jihan, wawancara data primer, 26 Februari 2018).

Hambatan teknis lainnya adalah $V R$ Innisfree mengalami beberapa kali kerusakan sebanyak empat kali dalam kurun waktu satu tahun terakhir.

Selain itu, dalam VR Innisfree terdapat guidance khusus yang harus dilakukan setiap harinya agar secara teknikal dapat berjalan sesuai dengan prosedur yang ada. Karena segala sesuatunya harus dikoordinasikan melalui agensi yang berada di Korea, hal tersebut tentunya memakan waktu yang cukup lama dalam hal perbaikan serta dari segi biaya juga cukup tinggi.

Permasalahan dari segi fasilitas menjadi suatu hambatan yang sangat diperhatikan Innisfree agar ke depannya pengguna kacamata dapat merasakan kenyamanan saat menggunakan kacamata $V R$. Hambatan tersebut dapat diatasi dengan baik melihat Innisfree sangat memperhatikan masalah yang menyangkut publik.

Pembahasan tersebut sesuai dengan pendapat (Kotler et al., 2009) mengenai alat utama yang digunakan dalam marketing public relations salah satunya adalah publik. Perusahaan dapat membangun citra positif dengan mengontribusikan uang dan waktunya untuk hal-hal yang positif.

\section{Hasil Realisasi Strategi MPR Innisfree}

Setelah merencanakan dan menjalankan suatu strategi marketing public relations tentunya terdapat hasil maupun feedback dari berbagai pihak yang terlibat salah satunya adalah Innisfree.

Realisasi dari strategi MPR untuk membangun citra Innisfree melalui penggunaan $V R$ sudah terealisasikan dengan baik. Hal tersebut terjadi karena Innisfree telah menetapkan perencanaan serta tujuan yang matang.

Strategi $M P R$ melalui penggunaan $V R$ dengan melakukan promosi secara online telah sukses dijalankan dan terealisasi dengan baik, dilihat dari cakupan dan ulasan dari berbagai pemberitaan media.

Hal tersebut sesuai dengan konsep strategi marketing public relations milik Smith (2013) mengenai tahap akhir dari evaluative research yaitu evaluating the strategic plan (mengevaluasi strategi perencanaan).

Tahap ini merupakan tahap akhir yang menunjukkan metode spesifik untuk mengukur keefektifan setiap taktik yang direkomendasikan dalam memenuhi tujuan yang dilakukan. Sama halnya yang dilakukan oleh Innisfree yaitu dengan mengukur keefektifan setiap strategi dan taktik yang dijalankan melalui umpan balik yang didapatkan dari beragam media salah satu yang paling efektif saat ini adalah melalui media online.

\section{Efek Citra Innisfree}

Citra Innisfree di mata publik saat ini sangat baik. Dimana Innisfree memiliki suatu keunggulan jika dibandingkan dengan merek kecantikan lain di antaranya dengan menyuguhkan strategi $M P R$ yang berbeda berupa penggunaan teknologi yang tengah berkembang saat ini yaitu $V R$.

"Terhadap citra baik banget ya. Karena dari sisi beauty brand waktu Innisfree mengeluarkan $V R$, mungkin beberapa tahun yang lalu belum banyak beauty brand yang sudah mengeluarkan $V R$. Jadi Innisfree termasuk brand beauty yang terdepan dalam hal teknologi." (Jihan, wawancara data primer, 26 Februari 2018). 
Dengan memasukkan suatu teknologi ke dalam dunia kecantikan menjadi hal yang baru tentunya tidak terkecuali bagi masyarakat Indonesia. Selain itu, Innisfree juga berhasil menawarkan publik sebuah pengalaman baru dalam dunia kecantikan yang mampu menciptakan opini positif terhadap perusahaan AmorePacific khususnya Innisfree.

Citra baik yang didapatkan Innisfree saat ini membuat Innisfree berhasil membangun citranya dimata publik. Dengan adanya respon positif dari publik, membuat Innisfree lebih mudah dalam menjalankan strategi-strategi lain dimasa yang akan datang agar dapat menciptakan citra yang terus meningkat di mata publik.

\section{Rencana dan Inovasi Innisfree}

Agar dapat terus berkembang dan membangun citranya di mata publik, diperlukan rencana serta inovasi-inovasi lainnya agar dapat mengembangkan strategi $M P R$ Innisfree, salah satunya adalah fitur $V R$ dari Innisfree.

Innisfree sendiri memiliki rencana untuk membuat konten-konten yang lebih menarik lagi mengenai $V R$ serta tidak lupa untuk melakukan evaluasi terkait efektivitas strategi $M P R$ yang dijalankan oleh Innisfree.

Innisfree tidak hanya berencana untuk memperbaiki kekurangan sistem dari $V R$ itu sendiri, tetapi juga Innisfree ke depannya akan memperhatikan konten-konten $V R$ yang lebih menarik lagi.

Tidak lupa, Innisfree juga tetap memberdayakan sistem evaluasi apakah strategi $M P R$ yang digunakan masih tetap efektif untuk dijalankan. Hal tersebut dilakukan Innisfree agar mendapatkan loyalitas dari publik terutama target pasar Innisfree yaitu kalangan milenial yang seringkali merasa cepat bosan terhadap halhal monoton.

\section{Harapan Innisfree Setelah Dilakukannya Pengembangan Fitur VR Innisfree}

Agar dapat lebih dikenal oleh publik, Innisfree berusaha membuat strategi $M P R$ berupa penggunaan $V R$ agar dapat mencapai tujuannya sebagai merek yang fokus terhadap segala keindahan yang terkandung pada Pulau Jeju.

Selain itu, Innisfree juga ingin agar publik dapat merasakan pengalaman yang ada di Pulau Jeju melalui Innisfree. Apabila pola pikir tersebut telah berhasil tertanam dalam publik, diharapkan publik dapat lebih familiar dan sadar mengenai Pulau Jeju dan Innisfree.

Penjelasan tersebut sesuai dengan jawaban dari MPR Innisfree, sebagai berikut:

"Harapannya balik lagi ke goal awal kenapa kita buat Innisfree $V R$, kita ingin orang-orang tahu bahwa Innisfree bukan hanya brand dari Korea, tapi Innisfree corenya adalah Jeju Island. Jadi kita ingin orang lebih mengenal atau bisa lebih experience Pulau Jeju secara langsung dan lebih aware dengan Innisfree dan konsep Jeju Island ini."

\section{Pembahasan}

Strategi marketing public relations untuk membangun citra Innisfree melalui penggunaan virtual reality telah memenuhi konsep strategi pull marketing public relations yang terdapat dalam buku Thomas L. Harris (2006) yang berjudul The Marketer's Guide to Public Relations.

Dalam strategi pull marketing public relations untuk membangun citra Innisfree melalui penggunaan virtual reality yang dilakukan adalah dengan banyak melakukan berbagai strategi komunikasi melalui pemberitaan online berupa Facebook Ads, Instagram Ads atau iklan di Google maupun Youtube.

Selain itu, menyediakan leaflet yang disebarkan di setiap gerai Innisfree serta berkoordinasi dengan beauty advisor untuk menarik minat publik terhadap Innisfree. Sejauh ini, cara yang paling efektif adalah dengan menggunakan pemberitaan secara online dimana feedback-nya dapat diterima dengan cepat. Kedepannya, Innisfree masih akan menerapkan sistem pemberitaan online dalam memperkenalkan video-video terbaru terkait $V R$.

Strategi pull lainnya adalah dengan memfokuskan kepada target audience Innisfree yaitu masyarakat milenial yang 
memiliki kisaran usia 18-35 tahun dengan mengadakan media event, kompetisi online serta dilakukannya mini survei usai menonton tayangan $V R$ dari Innisfree.

Sejauh ini, Innisfree memiliki tiga konten $V R$ Innisfree diantaranya: Flying Bike, Jeju Wonderland, dan Someday in Jeju. Melalui ketiga video yang ditampilkan tersebut, diharapkan dapat lebih mengenal potensi alam dan keindahan dari Pulau Jeju sebagai ikon dari Innisfree.

Dari segi respon yang diterima oleh Innisfree dari publik sejauh ini mendapatkan respon yang positif dan mendapatkan antusiasme yang tinggi dimana salah satu video $V R$ Innisfree yang bertemakan Someday in Jeju telah lebih dulu viral sebelum $V R$ Innisfree masuk ke Indonesia.

Untuk meningkatkan kinerja yang lebih baik lagi, Innisfree mendapatkan saran dari publik untuk membenahi permasalahan pada pengguna yang berkacamata. Agar dapat memenuhi permintaan dari publik, Innisfree menindak lanjutinya dengan mengirimkan saran tersebut ke pusat yang berada di Korea agar segera ditangani.

Dalam pelaksanaan strategi pull yang dilakukan oleh marketing public relations untuk membangun citra Innisfree melalui penggunaan $V R$ sejauh ini telah terealisasikan dengan baik, dapat dilihat dari adanya ulasan dan cakupan dari berbagai pemberitaan di media mengenai $V R$ Innisfree. Saat pelaksanaan strategi $V R$, terdapat dua pokok hambatan utama yaitu hambatan teknis dan fasilitas. Permasalahan teknis yaitu $V R$ Innisfree seringkali mengalami kerusakan sebanyak empat kali dalam waktu satu tahun terakhir sehingga seringkali $V R$ Innisfree tidak dapat digunakan, ditambah dengan aturan guidance yang perlu dijalankan secara rutin setiap harinya hal tersebut tentunya menelan biaya perbaikan yang tidak sedikit.

Hambatan dari segi fasilitas yaitu sampai saat ini pengguna kacamata masih mengalami rasa kesulitan dan ketidaknyamanan dalam pemakaian $V R$.

Setelah pelaksanaan strategi marketing public relations melalui penggunaan $V R$, citra yang didapatkan Innisfree sangat baik di mata publik. Citra tersebut didapatkan
Innisfree melalui penggunaan strategi unik yakni Innisfree menggabungkan sebuah teknologi dengan dunia kecantikan. Dua hal tersebut merupakan hal yang sangat diperhatikan bagi masyarakat saat ini.

Dengan menggunakan cara tersebut menjadikan Innisfree sebagai salah satu merek yang dikenal tidak hanya dari kualitas produknya saja, tetapi juga memperbarui dengan perkembangan teknologi saat ini. Innisfree juga memiliki caranya sendiri dalam mengukur keberhasilan dari strategi VR yang dijalankannya yaitu melalui komunikasi secara langsung dan komunikasi online.

Komunikasi secara langsung dapat dilihat dari respon publik saat mengunjungi gerai Innisfree serta komunikasi online dapat dilihat saat publik memberikan feedback berupa posting-an dan share yang ada di media sosial.

Ke depannya, Innisfree berencana untuk memperbaiki kekurangan sistem yang terdapat dalam VR Innisfree baik dari segi alat maupun fasilitas. Serta Innisfree akan terus menyajikan inovasi-inovasi baru dengan membuat beragam konten yang lebih menarik lagi agar dapat terus menyajikan konten yang segar dan baru.

\section{PENUTUP}

\section{Simpulan}

Strategi pull MPR yang digunakan Innisfree adalah dengan melakukan berbagai strategi komunikasi melalui pemberitaan online, penyebaran leaflet di setiap gerai dan berkoordinasi dengan beauty advisor.

Innisfree mengadakan kompetisi dan kuis secara online, mengadakan media event, dan melakukan survei di gerai $V R$ Innisfree. Innisfree menyajikan tiga konten video dengan pengalaman yang berbeda di setiap videonya dengan tujuan agar dapat lebih menekankan Pulau Jeju sebagai ikon dari Innisfree.

Hasil dari strategi pull MPR yang dilakukan oleh Innisfree adalah terus berkomunikasi dengan publik melalui saransaran yang diberikan serta terus berinovasi dengan menggunakan teknologi baru yang 
didukung dengan konten yang menarik dan terbaru. Melalui strategi pull MPR yang dilakukan oleh Innisfree menunjukkan bahwa Innisfree telah berhasil membangun citra yang diinginkannya (wish image) sebagai merek berkonsep natural yang terdepan dalam bidang teknologi.

\section{Saran}

Adanya penelitian yang lebih mendalam mengenai strategi marketing public relations dengan menggunakan teori maupun konsep serta fokus yang berbeda pada penelitian selanjutnya. Meningkatkan publikasi mengenai $V R$ melalui sosial media, iklan Ads (Google, Facebook, Instagram, Youtube).

Mengaktifkan komunikasi melalui email blast. Dengan mengaktifkan email blast, tentunya akan lebih memudahkan bagi Innisfree untuk mengirimkan publikasi mengenai $V R$ Innisfree kepada seluruh member Innisfree.

Melakukan hal-hal yang berkaitan dengan charity, local/national sponsorships yang merupakan bagian dari tools $M P R$ strategi pass yang terdapat dalam three ways strategies.

\section{DAFTAR PUSTAKA}

Ardianto, E. (2010). Metode Penelitian Untuk Public Relations Kuantitatif dan Kualitatif. Bandung: Simbiosa Rekatama Media.

Harris, T. L., \& Whalen, P. T. (2006). The Marketer's Guide to Public Relations in the 21st Century. Ohio: Thomson Higher Education.

Innisfree. (2017). Tentang Innisfree "Konsep Brand." Retrieved from http://www.innisfree.com/id/id/BrandPage .do?pageName=brand_concept [Accessed: March 28, 2018].
Jefkins, F. (2002). Public Relations. Jakarta: Penerbit Erlangga.

Jerald, J. (2016). The VR Book "HumanCentered Design for Virtual Reality." New York: ACM.

Kemenperin. (2016). Berita Industri: Produk Impor Kuasai Pasar Kosmetik. Retrieved from

http://www.kemenperin.go.id/artikel/1194 3/Produk-Impor-Kuasai-Pasar-Kosmetik [Accessed: March 25, 2018].

Kotler, P., Keller, K. L., Ang, S. H., Leong, S. M., \& Tan, C. T. (2009). Marketing Management: An Asian Perspective (5th Ed.). Singapore: Pearson Education South Asia.

Oliver, S. (2007). Strategi Public Relations. Jakarta: Penerbit Erlangga.

Saggio, G., \& Ferrari, M. (2012). New Trends in Virtual Reality Visualization of 3D Scenarios. In Virtual Reality - Human Computer Interaction. doi:10.5772/46407

Smith, R. D. (2013). Strategic Planning for Public Relations. New York: Sheridan Group.

Sukmadinata, N. S. (2007). Metode Penelitian Pendidikan. Bandung: Remaja Rosdakarya.

Tranggono, R. I., \& Latifah, F. (2007). Buku Pegangan Ilmu Pengetahuan Kosmetik. Jakarta: PT. Gramedia Pustaka Utama.

Wahid, U., \& Puspita, A. E. (2017). Upaya Peningkatkan Brand Awareness PT . GoJek Indonesia Melalui Aktivitas Marketing Public Relations. Jurnal Komunikasi, 9, 31-43.

Wasesa, S. A., \& Macnamara, J. (2010). Strategi Public Relations. Jakarta: PT. Gramedia Pustaka Utama.

Wulandari, D. (2016). Ramai Brand Korea Bertarung di Pasar Kosmetik, Siapa Menang? Retrieved from https://mix.co.id/marcomm/newstrend/ramai-brand-korea-bertarung-dipasar-kosmetik-siapa-menang [Accessed: March 15, 2018]. 